\title{
The effect of saturation degree of cement paste on fair-faced concrete surfaces
}

Kitti KÁROLYFI

Graduated as an Architect at István Széchenyi University in 2016. PhD student at the

Department of Structural and Geotechnical Engineering (SZE). Main research area: concrete technology, fair-faced concrete.

KıтTı KÁROLYFI - István Széchenyi University, Department of Structural and Geotechnical Engineering " k.kitti93@gmail.com

Érkezett: 2017. 03. 30. " Received: 30. 03. 2017. " https://doi.org/10.14382/epitoanyag-jsbcm.2017.10

\begin{abstract}
The aim of this study is to examine the quality of fair-faced concrete surfaces with respect to differently saturated mixtures. Technical literature recommends an oversaturated concrete composition with $20-40 \mathrm{l} / \mathrm{m}^{3}$ in the case of fair-faced concrete [1]. This paper evaluates the implementation of 4 mixtures made with different saturation degree $\left(22,55,88,121 \mathrm{l} / \mathrm{m}^{3}\right)$ of the cement paste, fixed quality formwork and release agent. A unique formwork was used for implementation of the specimens, which enabled to examine the critical points of the fairfaced concrete technology (oblique surfaces, sharp-angled corner, exclusion) and the effect of the different absorbent form liners (plywood and steel). The main aspects of the evaluation of the surfaces were porosity, discoloration and the texture based on Hungarian standard [2] and German guideline [3]. Compressive strength of mixtures was examined on standard cubes at 7 and 28 days of age. Based on the results the optimal saturation degree was high beyond the recommended value in the tested range with respect to the surface quality of the specimens. However, the compressive strength was reduced by increasing the saturation degree, which is an observable point in the design of fair-faced concrete members.

Keywords: fair-faced concrete, concrete technology, saturation degree, surface-quality
\end{abstract}

\section{Introduction}

In the last decades the concrete as a building material got a reinterpretation. The XXI century's concrete architecture is characterized by multifarious forms and high surface-quality. This quality is influenced by numerous factors, for example the material and geometry of the applied formwork, the concrete composition, the applied release agent, the environmental conditions and the construction work. Therefore, the reason of the occurring defects of the surface appearance can be hardly discovered and the surface is not reparable afterwards. The goal of this research is the examination of the fair-faced concrete surfaces referring to the different saturation degree of cement paste of the concrete composition. According to the literature in the case of fair-faced concrete the application of an oversaturated mixture with a value of $20-40 \mathrm{l} / \mathrm{m}^{3}$ is recommended [1]. Accordingly this research includes a wider examination of the oversaturated mixtures with a value from a nearly saturated mixture $\left(22 \mathrm{l} / \mathrm{m}^{3}\right)$ to a significantly oversaturated mixture $\left(121 \mathrm{l} / \mathrm{m}^{3}\right)$, increasing it in 3 steps.

\section{Applied materials}

\subsection{Concrete technology}

4 concrete mixtures were prepared in the laboratory of Holcim Zrt. in Györ, according to Table 1. In the course of the research CEM I 52,5 N white cement was used in order to facilitate the discovering of the surface defects. The applied material was produced in one cycle therefore there was a constant quality provided during the research. Schlumpf et al [4] recommended the application of cement content with a minimum value of $300 \mathrm{~kg} / \mathrm{m}^{3}$ in the case of fair-faced concrete. For this reason the first mixture was designed with a cement content of $320 \mathrm{~kg} / \mathrm{m}^{3}$ and a water content of $160 \mathrm{~kg} / \mathrm{m}^{3}$, which was a nearly saturated $\operatorname{mix}\left(\mathrm{V}_{\mathrm{sa}}=+22 \mathrm{l} / \mathrm{m}^{3}\right)$. The main variable parameters were the amount of cement, water and the aggregate, and therefore the saturation degree of the cement paste, assuring a constant water to cement ratio.

In all mixtures the same type of aggregate (sand and gravel from Danube River) was used. In all cases a fixed proportion of particle size distribution was applied as $48 \%$ sand $(0-4 \mathrm{~mm})$,

\begin{tabular}{|c|c|c|c|c|c|c|c|}
\hline Mixtures & $\begin{array}{c}m_{c} \\
\text { Cement }\left(\mathbf{k g} / \mathbf{m}^{3}\right)\end{array}$ & $\begin{array}{c}\mathbf{V}_{w} \\
\text { Water }\left(I / \mathbf{m}^{3}\right)\end{array}$ & $\underset{\text { Aggregate }}{\mathrm{m}_{\mathrm{a}}}\left(\mathrm{kg} / \mathrm{m}^{3}\right)$ & $\begin{array}{c}m_{\mathrm{pl}} \\
\text { Plasticizer } \\
\left(\mathbf{k g} / \mathrm{m}^{3}\right)\end{array}$ & $\begin{array}{c}\mathbf{V}_{\text {sa }} \\
\text { Value of Saturation } \\
\left(\mathrm{l} / \mathrm{m}^{3}\right)\end{array}$ & $\begin{array}{c}\text { w/c } \\
\text { Water to } \\
\text { cement ratio }\end{array}$ & $\begin{array}{c}\text { Consistency class } \\
\text { (flow table test) } \\
\text { [5] }\end{array}$ \\
\hline 1 & 320 & 160 & 1919 & 2,8 & +22 & 0.50 & F4 \\
\hline 2 & 360 & 180 & 1832 & 1,5 & +55 & 0.50 & F4 \\
\hline 3 & 400 & 200 & 1745 & 1,0 & +88 & 0.50 & F4 \\
\hline 4 & 440 & 220 & 1658 & 0 & +121 & 0.50 & F4 \\
\hline
\end{tabular}

Table 1. The parameters of the examined concrete mixtures

1. táblázat A 4 vizsgált betonösszetétel jellemzö paraméterei 
$20 \%$ small gravel (4-8 mm), and $32 \%$ medium gravel (8-16 mm), respectively. Maximum size of aggregate was $D_{\max }=16 \mathrm{~mm}$.

\subsection{Formwork}

Two main aspects were considered in the design process of the formwork. In one hand the performance of the formwork should enable the examination of the critical points of fairfaced concrete technology. According to Fig. 1 it has a thin, wall-like geometry, whose one side is beveled in order to examine the differences of the porosity of the differently positioned surfaces. It allows to discover to what extent can the differently oversatured mixtures fulfill the sharp-angled $\left(54^{\circ}\right)$ corner. There was an exclusion created on the one vertical side of the formwork in order to examine the development of the blisters in this sensitive area too.

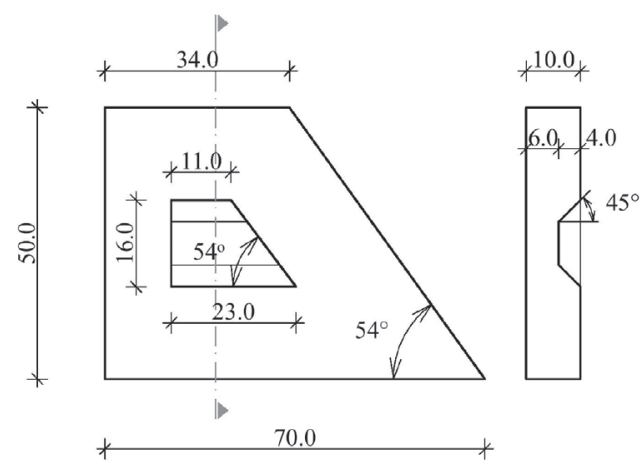

Fig. 1. Performance of the applied formwork $(\mathrm{cm})$

1. ábra Az alkalmazott zsaluzat terve $(\mathrm{cm})$

On the other hand the examination of the effect of the differently saturated concrete mixtures and differently absorbent form liners on concrete surfaces was an important aspect too. Hence steel plate and plywood was used as form liners according to Fig. 2. SIKA Release agent 2a was used as form release agent, this is a solvent-free, mineral-oil based release agent for metal, wood and plastic.

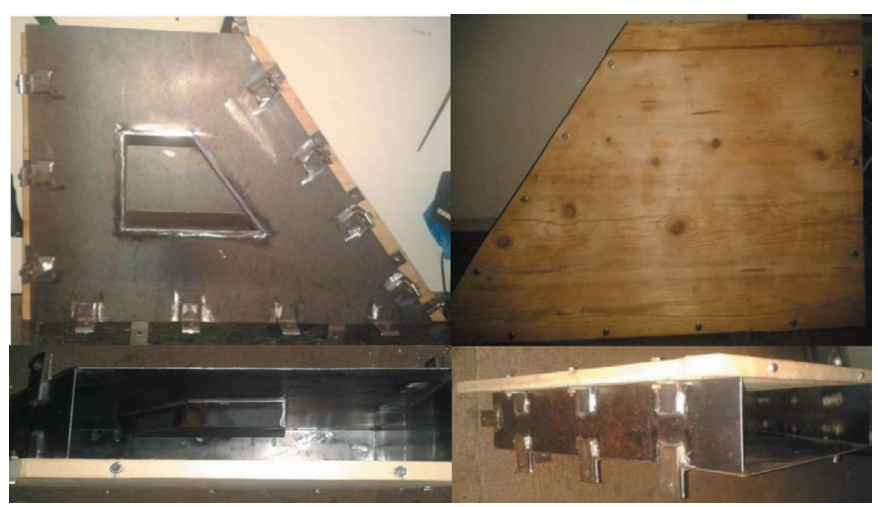

Fig. 2. The applied form liners

2. ábra Azalkalmazott zsaluhéjak

\subsection{Construction work}

The consistency class was obtained by performing the most diluted (4.) mixture, using flow table test. The constant consistency class (F4) in the case of the other mixtures was assured by applying plasticizer. The mixtures were filled in the formwork in three layers and were compacted on a vibrating table. The test pieces were kept in the formwork for 3 days as curing.

\section{Aspects of the evaluation}

The evaluation of the test pieces was accomplished based on MSZ 24803-6-3:2010 [2] and the German Code of Practice for Fair-Faced Concrete [3] edited by German Concrete and Construction Engineering Association (DBV) and the Federal German Association of the Cement Industry (BDZ). The obtained results were compared to each other. The main aspects of the examination were the porosity, the discoloration and the texture (honeycombing). In addition, the 7 - and the 28-days compressive strength of the mixtures was examined on standard cube specimens.

\section{Experimental results}

\subsection{Examination of the porosity}

Despite of the careful design and construction work the formation of pores is unavoidable. The porosity of the concrete surface must not exceed the limit value of the given concrete class defined by the standards. According to the Hungarian standard and the German guideline the pores with a diameter of 1-15 $\mathrm{mm}$ and $2-15 \mathrm{~mm}$ were taken into account $[2,3]$. The examination was accomplished on each surface of the 4 specimens. As the area of the pores smaller than $2 \mathrm{~mm}$ is minimal, the difference between the porosity values of the two standards was negligible. In pursuance of the evaluation there were 3 surface groups defined depending to their position to the pouring-in direction (Fig. 3):

- P1-5 (vertical) surfaces: Parallel with the pouring-in direction

- V1 (horizontal) surface: Perpendicular to the pouringin direction

- F1-4 (beveled) surfaces: Angular with the pouring-in direction.

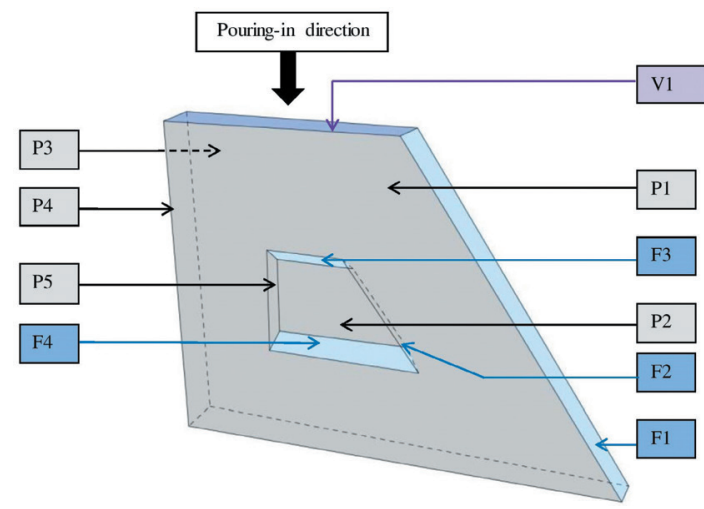

Fig. 3. Grouping of the surfaces

3. ábra Felületek csoportosítása

Fig. 4 illustrates the results of the porosity examination of the specimens by surface groups. The most significant change was shown in the surrounding area of the exclusion on the surfaces P2 and P5 (Fig. 5), and on the beveled surfaces F1 (Fig. 6). Increasing the saturation degree to the value of $88 \mathrm{l} / \mathrm{m}^{3}$ - which is nearly fourfold of the recommended value - the porosity 


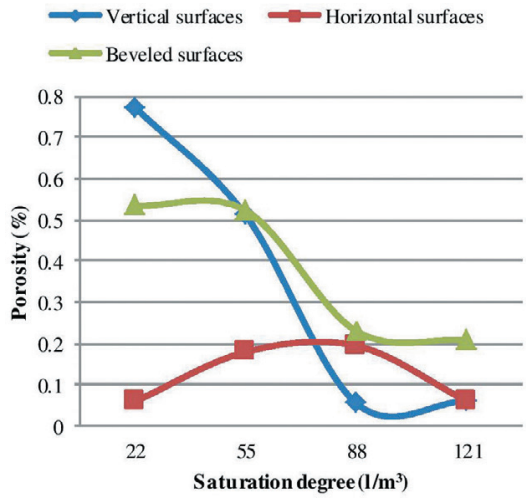

Fig. 4. The average porosity of surface groups by cement slurry saturation 4. ábra Felületcsoportok átlagos pórustartalmának változása a péptelítettség növekedésével

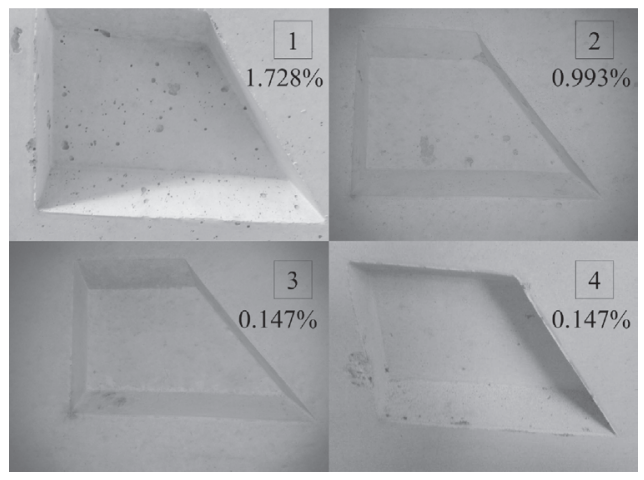

Fig. 5. Porosity of the surface P2 of the 4 specimens

5. ábra A 4 próbatest $P 2$ felületének porozitás változása

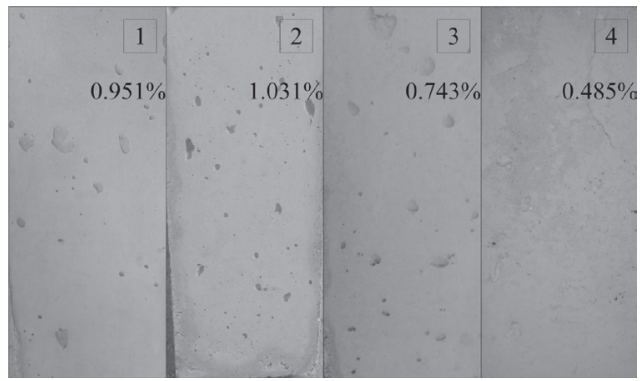

Fig. 6. The change of the porosity of the surface F1 by specimens 6. ábra F1-es felület pórustartalmának változása próbatestenként

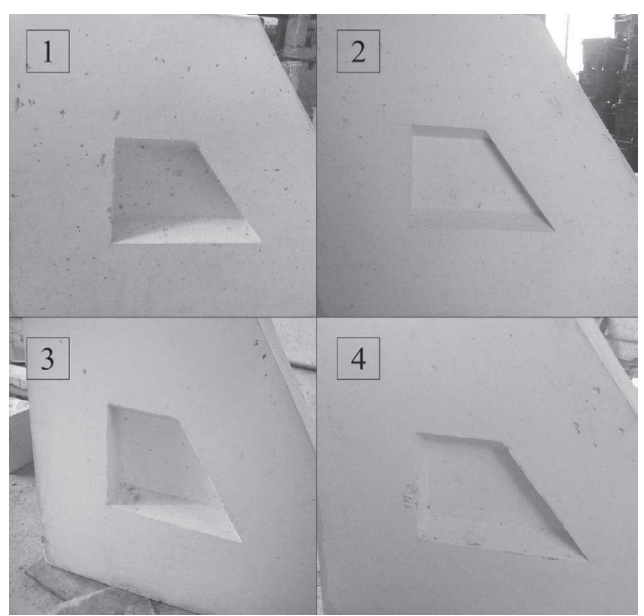

Fig. 7. The porosity of surfaces made by steel form liner 7. ábra Fém zsaluhéjjal készült felületek pórustartalma of the vertical surfaces decreased with $90 \%$ and the beveled surfaces' with $66 \%$ on average. The porosity of surfaces made by unabsorbent (steel) form liners was more than $90 \%$ higher, than the maximal porosity of surfaces made by absorbent (plywood) form liner. In regard to the porosity, the last specimen, made with significantly oversaturated mixture (121 $1 / \mathrm{m}^{3}$ ) can be classified into the highest fair-faced concrete class according to both the Hungarian and German guidelines. This establishment can be confirmed by visual inspection too, see Fig. 7. The porosity of surfaces made by absorbent form liner did not even reach the limit of the highest concrete class (MSZ: 0,6\%, DBV: $0,3 \%$ ) in the case of every specimens. Considering the average porosity of the surface groups the optimal degree of saturation was between 88 and $121 \mathrm{l} / \mathrm{m}^{3}$ in the tested range.

\subsection{Discoloration}

Regarding the discoloration it is expedient to examine the surfaces made by absorbent and unabsorbent form liners separately. On the surfaces made by plywood (P3) some dark discolorations were shown on the first three specimens, which can be explained with the local difference of absorbency of the form liner [6] (see Fig. 8). The degree of the dark coloration decreased and became even smoother by increasing the level of oversaturation. The surfaces made by steel form liner were selfcolored, but the other surface defects were more conspicuous. As a result of visual inspection the fourth specimen - where the value of oversaturation was $121 \mathrm{l} / \mathrm{m}^{3}$ - showed absolutely homogeneous surface quality. Additionally, this specimen can be classified into the highest class (FT3) of texture based on the German guideline.

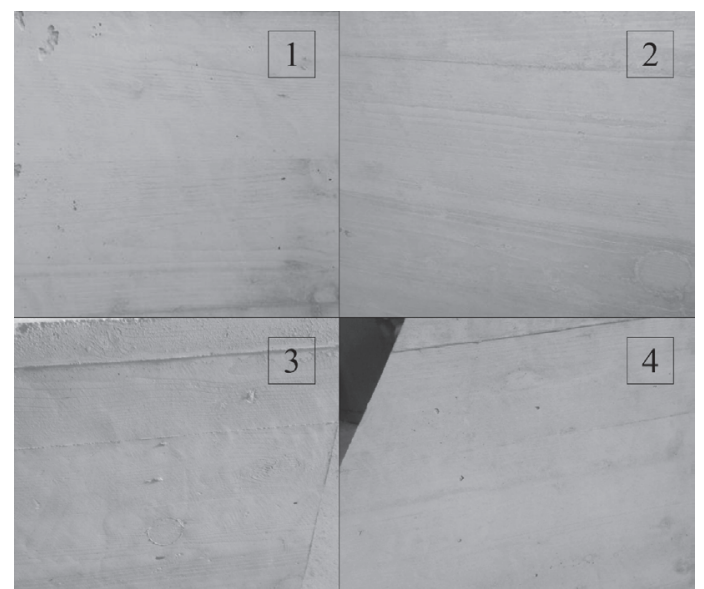

Fig. 8. The discoloration of surface P3, made by absorbent form liner

8. ábra P3-mas, nedvszívó zsaluhéjjal készült felület elszíneződései próbatestenként

\subsection{Texture}

In the course of the experiment the right and sharp-angled corner of the specimens showed honeycombing. The joints of the form liners were leak on purpose to examine the sensitivity of the different mixtures to this phenomenon under the same circumstances. In the case of honeycombing any unequivocal trend cannot be established in the tested range. The degree of honeycombing was a bit higher in the case of the fourth specimen, otherwise the test pieces were nearly equivalent, see Fig. 9. 


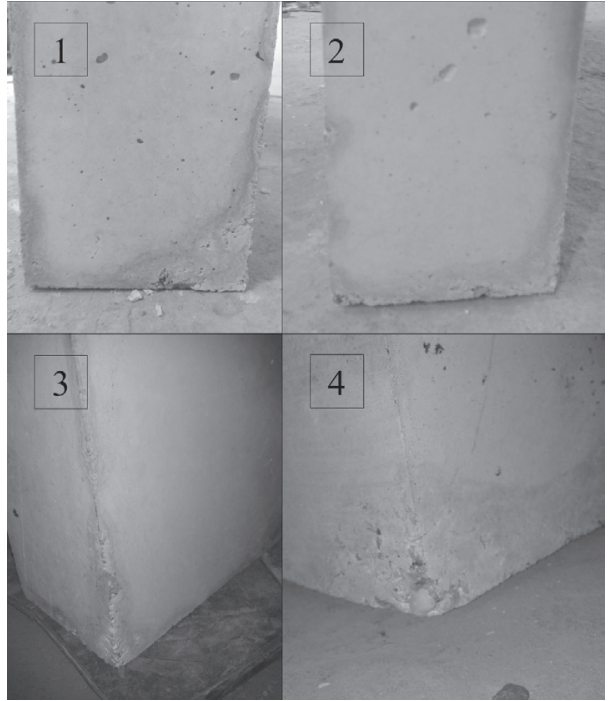

Fig. 9. Honeycombing in the corner of the 4 specimens

9. ábra Fészkesedés a próbatestek sarkában

\subsection{Compressive strength}

In the point of the compressive strength the hardened cement paste gets a greater significance with increasing saturation degree of the concrete composition [7]. Since the strength of the aggregates used is generally higher, than that of the cement paste, obviously the higher saturation degree of cement paste used, the lower the compressive strength of concrete. The values of the compressive strength with respect to saturation degree are presented in Fig. 10. At the age of 7 days, concrete mixtures showed a decrease of $7 \%$ in compressive strength, and a decrease of $9.8 \%$ is corresponding to the age of 28 days. The relationship between compressive strength and saturation degree was found to be nearly linear in the tested range.

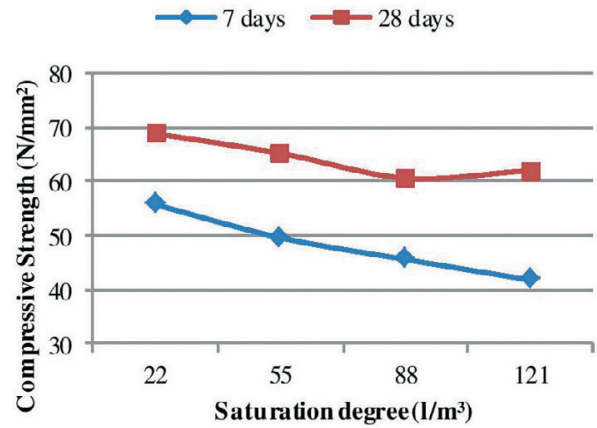

Fig. 10. The values of 7-and 28-days compressive strength with respect to the saturation degree [8]

10. ábra A 7 és 28 napos nyomószilárdsági értékek a péptelitettség függvényében [8]

\section{Conclusions}

The classification of the test pieces based on the German guideline is shown in Table 2. Based on the presented examination concerning the effect of different levels of saturation on fairfaced concrete surfaces, the following conclusions can be drawn:

- The overall surface-quality of the mixtures became even higher with increasing saturation degree in the tested range.

- Based on the previous result the optimal level of saturation was between 88 and $121 \mathrm{l} / \mathrm{m}^{3}$, which noticeably exceeds the recommended value $\left(20-40 \mathrm{l} / \mathrm{m}^{3}\right)$.
- The surface-quality in the critical points (the sharpangled corner, the environment of exclusion) increased significantly with the higher saturation degree.

- There was a difference between surfaces in different positions; the porosity of vertical surfaces was averagely higher, than the beveled surfaces', and the lowest was the horizontal surfaces'.

- The porosity of the surfaces made by absorbent form liner was appreciably lower, than in the case of unabsorbent form liner.

- The surfaces made by absorbent form liner showed more discolorations.

- In the case of oversaturated mixtures the sealing of joints is especially important.

- The increase of saturation degree improved the quality of the surfaces made by unabsorbent form liner to a great extent.

- The examination of compressive strength of the specimens confirms that higher saturation degree reduces the value of compressive strength [7].

\begin{tabular}{|c|c|c|c|c|c|c|c|}
\hline \multirow{3}{*}{ Mixtures } & \multicolumn{7}{|c|}{ Aspects of evaluation } \\
\hline & \multicolumn{2}{|c|}{ Porosity } & \multicolumn{2}{|c|}{$\begin{array}{l}\text { Discolor- } \\
\text { ation }\end{array}$} & \multicolumn{2}{|c|}{ Texture } & \multirow[t]{2}{*}{$\begin{array}{c}\text { Classification } \\
\text { [3] }\end{array}$} \\
\hline & $\mathbf{U}$ & A & $\mathbf{U}$ & A & $\mathbf{U}$ & A & \\
\hline 1. & - & P4 & FT3 & FT1 & T3 & T2 & - \\
\hline 2. & P1 & P3 & FT3 & FT1 & T3 & T2 & SB2 \\
\hline 3. & P2 & P4 & FT3 & FT2 & T3 & T2 & SB3 \\
\hline 4. & P3 & P4 & FT3 & FT3 & T3 & T2 & SB4 \\
\hline
\end{tabular}

Table 2. Classification of the specimens by the German Code of Practice for Fair-Faced Concrete (A: absorbent, U: unabsorbent form liner) [3]

2. táblázat Próbatestek osztályba sorolása a „Merkblatt Sichtbeton” vizsgálati szempontjai alapján (A: nedvszivó, U: nem nedvszivó zsaluhéj) [3]

\section{References}

[1] Kapu László: Látszóbeton - Látványbeton, TERC Kft., Budapest, 2014.

[2] MSZ 24803-6-3:2010. Épületszerkezetek megjelenési módjának előírásai. 6-3. rész: Monolit beton- és vasbeton szerkezetek. A helyi alakhűség és a felületi állapot követelményei (Specifications for appearance of building structural elements. Part 6-3: Specifications for appearance of concrete and reinforced concrete structures. Requirements for local surface conditions and shape conformity)

[3] DBV/BDZ-Merkblatt Sichtbeton, Deutscher Beton- und BautechnikVerein e.V. Berlin, und Bundesverband der Deutschen Zementindustrie, Köln, 2004.

[4] Dipl.-Ing. HTL Jürg Schlumpf - Dipl.-Ing. Bastian Bicher - Dipl.-Ing Oliver Schwoon: Sika Beton Handbuch, Sike Services AG, Zürich, 2013.

[5] EN 12350-5:2009. Testing fresh concrete - part 5: Flow table test

[6] Doris Elisabeth Strehlein: Fleckige Dunkelverfärbungen an Sichtbetonoberflächen - Charakterisierung - Entsehung - Vermeidung, PhD Dissertation, Technische Universität München, Lehrstuhl für Baustoffkunde und Wersktoffprüfung, München, 2012.

[7] Dr. Balázs György: Barangolásaim a betonkutatás területén, Akadémiai Kiadó, Budapest, 2001.

[8] EN 12390-3:2009. Testing hardened concrete. Compressive strength of test specimens

Ref.:

Károlyfi, Kitti: The effect of saturation degree of cement paste on fairfaced concrete surfaces

Építőanyag - Journal of Silicate Based and Composite Materials,

Vol. 69, No. 2 (2017), 55-58. p.

https://doi.org/10.14382/epitoanyag-jsbcm.2017.10 